\title{
Detecting and Deterring Not-for-Profit Organization Accounting Fraud
}

\author{
Wayne Balfour \\ Liberty University
}

\author{
Gene Sullivan \\ Liberty University
}

\author{
Stanley Self \\ Purdue Global University \\ Rachel Byers \\ Purdue Global University
}

\begin{abstract}
This study contributes to the body of literature about detecting and deterring accounting fraud in not-forprofit organizations. More specifically, the purpose of this qualitative case study was to explore opportunities for not-for-profit and religious not-for-profit organizations to detect and deter accounting fraud. The researchers incorporated data collected from not-for-profit organizations in New Jersey. One finding of this current study validates previous studies and the emphasis on the need for specific and ongoing accounting training. Additional findings confirm the need for enhanced accounting internal controls within not-for-profit organizations. The study results indicate RNPOs with larger budgets, and staff tend to have more reliable internal accounting controls. The authors identify additional implications. Organizations need to employ a CPA or a financial professional, raise fraud awareness, and develop continuous fraud training for key leaders. Finally, RNPOs need to create and articulate their fraud policies.
\end{abstract}

Keywords: fraud, accounting fraud, fraud in NFPs, accounting training, accounting education

\section{INTRODUCTION}

Accounting fraud has caused significant financial losses, devastated organizations, and affected society at large. Independent of the financial losses, fraud has caused immeasurable damage to the overall economy and investor confidence (Dong et al., 2018). As a result, extensive research has examined fraud in the corporate sector (Sorunke, 2016). Many fraud mitigating measures and have been identified, including effective governance, strong internal controls, and the importance of ethical leadership (Bernstein et al., 2016; Harris et al., 2017; Pickerd et al., 2015; Schaubroeck et al., 2012).

Although less documented, fraud in not-for-profit organizations (NPOs) is widespread (Archambeault \&Webber, 2018; Archambeault et al.,2015; Harris et al., 2017). NPOs, and more specifically, religious notfor-profit organizations (RNPOs) are intimately intertwined into every sector of society. The United States 
and other countries have experienced a proliferation of RNPOs over the past century. Those RPNOs attempt to manage some of the social maladies attributable to growing, diverse populations. Haynes (2009) posited that faith-based organizations (FBOs) deliver a variety of services to the public in the form of elder care, justice advocacy for the oppressed, humanitarian aid, and international development efforts. Several major universities, hospitals, civic, and charitable organizations have religious origins. For example, a few recognizable RNPOs include The YWCA and YMCA, The Salvation Army, and The Knights of Columbus. Yet, even with their prevalence, fraud in RNPOs organizations has had relatively little attention compared to the corporate world (Harris et al., 2017). The objective of this study is to contribute to the body of knowledge related to fraud in these organizations.

The manner in which these organizations function further contributes to the need for research. That is, RNPOs' existence and survival are heavily dependent upon grants, voluntary donations from donors, and inexpensive or free labor of volunteers. Further, many of these donations are received in cash. As a result, fraud can have a considerable impact on a RNPO's ability to secure those resources. Hager and Hedberg (2016) found that the news of scandals and negative press often weakened the confidence of the general public, resulting in lower donations to RNPOs. Hou et al. (2017) suggest that trust is the dynamic that motivates prospective and actual donors. Further, broken or damaged trust related to adverse events such as fraud, is an obstacle that prevents the public from giving donations. Studies of defunct RNPOs found that the loss of public trust may have been partly to blame for the organization's demise. Administrators of RNPOs have suggested that the public is not only concerned about the execution of the mission of the organization, but it is also concerned about the financial stewardship of the organization. France and Tang (2018) suggested that funders and donors expect non-profit organizations (NPO) to fulfil their missions.

Prior research includes studies that have argued that philanthropic organizations are more prone to fraud for a variety of reasons, including: poor leadership, placing significant trust in ill-equipped staff, and poor internal controls (Harris et al., 2017; Shaharuddin \& Sulaiman, 2015). Though most RNPOs exist for noble, charitable or socio-economic philanthropic purposes, the reality is their leadership is ultimately responsible for the proper stewardship of donations and resources. Kummer et al. (2015) argued that NPOs heavily depend on volunteer support, and as a result, leadership of some smaller NPOs may not have the relevant expertise and resources to prevent fraud.

As in the corporate sector, one of the tools that management of RNPOs use to reduce the incidence of fraud is internal controls. Unfortunately, NPOs often lack adequate controls for detecting and deterring fraud (Archambeault et al., 2015; McDonnell \& Rutherford, 2018). Archambeault and Webber (2018) and Fitzgerald et al. (2018a) argued that internal controls within NPOs are especially inadequate.

The fundamental aim of this study is to contribute to the body of literature that exists RNPOs internal accounting controls, governance practices, stewardship, and tools, such as internal controls, that are available to them for deterring accounting fraud in their organizations. More specifically, the purpose of this qualitative case study was to explore leaders of religious not-for-profit organizations throughout the New Jersey and their ability to detect and deter accounting fraud. Prior research related to fraud detection and prevention (Patelli \& Pedrini, 2015; Schaubroeck et al., 2012; Bernstein et al., 2016), informed the research question (RQ) for the current study. Specifically, as it relates to NPOs in New Jersey: Is there a relationship between leadership competence, leadership style, and accounting fraud detection?

The literature review examines various types of accounting fraud in NPOs. In addition, a review of the research related to fraud mitigating measures including governance, leadership styles, and ideal accounting practices for RNPOs is presented. Next, the Research Design section focuses on study methodology, including sub-sections on sample selection and data collection. The results of the study and the analyses of those results are presented in the Results; the conclusion explains the implications of these results.

\section{LITERATURE REVIEW}

\section{Accounting Fraud}

Accounting fraud has caused devastating financial losses, destroyed organizations, and significantly impacted society. Apart from the tremendous financial losses, fraud has caused immeasurable damage to 
the overall economy and investor confidence (Dong et al., 2018). Fraud in organizations can have damaging reactions and an adverse effect on an entities' credibility, especially with the advent of powerful online communication tools like social media and blogs. Negative comments can bring harmful results and longlasting consequences that could cripple or put organizations out of business (Milde \& Yawson, 2017).

To determine the risk associated with fraud, it is imperative for leaders of RNPOs to understand what fraud is. Jackson (2015) identified financial fraud as the act of deception and misrepresentation with the intent to deceive. Financial fraud and financial exploitation involve perpetrators using a position of trust to misappropriate assets (Jackson, 2015). More formally, the Association of Certified Fraud Examiners (ACFE) defined internal fraud, also known as occupational fraud, as: "the use of one's occupation for personal enrichment through the deliberate misuse or misapplication of the organization's resources or assets" (ACFE, 2019a, p.1). Or simply stated, this type of fraud occurs when "an employee, manager, or executive commits fraud against his or her employer" (Sabau, 2012, p. 111).

According to Gibson (2017), non-occupational fraud occurs when a vendor, customer, or client defrauds an organization of its resources. An example of non-occupational fraud is when a vendor has insider trading information about a company that she or he can sell to gain a financial advantage. ACFE (2019a) developed the most comprehensive taxonomy fraud classification model. Better known as the 'fraud tree,' the model outlines 49 different individual fraud schemes, grouped into three main categories and a few subcategories, in Table 1. ACFE summarizes the 49 types into three broad categories.

TABLE 1

\section{ACFE FRAUD CLASSIFICATION}

\begin{tabular}{lll}
\hline Asset Misappropriation & Financial Statement & Corruption \\
\hline Skimming of cash & Asset and revenue overstatement & Illegal gratuities \\
Theft of inventory & Asset and revenue understatement & Bribery \\
Theft of office equipment & & Conflict of interest \\
& & Economic extortion \\
Fraudulent disbursements & & Financial kickbacks \\
\hline
\end{tabular}

\section{Adapted From ACFE Fraud Tree}

Asset misappropriation is the most common type of fraud; it is perpetrated primarily by lower-level employees (O'Gara, 2014). Managers are also malefactors of this type of fraud; the primary difference is the size of the organizations' loss. According to ACFE's (2020) report to the nations, management misappropriated an average of $\$ 850,000$ or six times what other lower-level employees stole from organizations. O'Gara (2014) suggested that customers, vendors, and other third parties may also act as fraudsters. The primary methods of asset misappropriation fraud include theft by employees in the form of cash and assets, embezzlement, payment scams, and fraudulent disbursements (ACFE, 2019b; Tinkelman \& Song, 2012). NPOs encounter the risk of fraud in many ways, including risk associated with donations. Murphy (2015) identified the following are some common examples misappropriation of funds fraud issues that NPOs may encounter:

1. Abuse of credit card privileges for personal use.

2. Forgery of checks by using RNPOs checks for personal bills and individual purchases.

3. Stolen donations, especially with significant cash transactions events with little or no oversight.

4. Forgery of checks.

5. Misclassification of restricted donations.

ACFE (2020) found that in 114 countries, $83 \%$ of all fraud was the misappropriation of funds. This type of fraud is not reported by $66 \%$ of corporations, and as much as $95 \%$ of all fraud in RNPOs goes undetected and/or unreported (Majid et al., 2016; Palvo, 2013; Thornhill \& Domino, 2016). Thus, the misappropriation of funds is an epidemic in many types of organizations throughout the world. 
Financial statement fraud in RNPOs is more likely to be perpetrated by trusted employees who do understand proper accounting practices. Albrecht et al. (2015) stated that financial statement fraud is ordinarily a top-down type of fraud that adversely influences individuals, organizations, and society. This type of fraud primarily involves employee-collusion. Further, it typically includes one or more members of executive management, such as the chief executive officer (CEO), chief financial officer (CFO), or chief operations officer (COO), manipulating the financial statements because of some type of internal or external pressure to show an excellent performance of the organization (Albrecht et al., 2015, Self, et al., 2016). Financial statement fraud involves an overstatement or understatement of the financial position of an entity. The ACFE Report to the Nations on Occupational Fraud and Abuse stated that financial statement fraud accounts for nine percent of all fraud, amounting to nearly $\$ 1$ million per occurrence and accounts for billions lost by organizations annually (ACFE, 2019a).

The final general category of fraud RNPOs are most likely to suffer is corruption. According to ACFE (2019a), corruption can be defined as the wrongful use of influence to benefit oneself or another person, contrary to their duties or rights as principal or agent of that organization. There are two types of bribery associated with corruption (ACFE, 2019a). The first is commercial bribery, in which a private individual engages in a commercial transaction with the intent to obtain a commercial or business competitive advantage. The second is official bribery, in which a government official uses his or her position to unduly influence an act of government. Some methods of corrupt payment include the following: (a) inappropriate or excessive gifts, (b) loans that will never be repaid, (c) the use of the organizations credit cards to make personal payments to the fraudster, (d) sexual favors in lieu of the organization's assets, (e) overpayment on purchases with the intent to receive kickbacks, (f) free use of the organization's or the use of the organization's vehicles for free and not for the organization's purpose, $(\mathrm{g})$ selling or leasing the organization's assets for less than fair market value with the intent of obtain quid pro quo or kickbacks, or (h) simply promise of favorable treatment (ACFE, 2019a). This is a comprehensive list of possible corruption that may occur in RNPOs that may be innocent or deliberate.

RNPOs or FBOs are more susceptible to each type of fraud mentioned. Depending on the size of the organization; these types of crimes can go undetected for years. Churches receive cash offerings; in the absence of checks and balances, a fraudster can skim cash, a misappropriation of funds, without anyone's knowledge. In the case of financial statement fraud, many RNPOs extend significant trust to staff. RNPOs or FBOs are at high risk for corruption, as well.

For example, without internal controls, a small loan may remain undetected and undetected for years. The use of the organization's vehicle by the volunteers or staff for non-business-related activities may be part of the culture. Volunteers may see it as reimbursement for their services, although they are volunteers. All of the above are crimes against RNPOs, and comprise just some of the many possible scenarios that may undermine an organizations' ability to effectively fulfill their mission. Administrators and management may have effective leadership skills in developing the organization but may lack the financial competence.

\section{Religious Not-for-Profit Organizations}

RNPOs, or FBOs, are organizations that are created with charitable missions. Backer (2016) noted that religion plays an unquestionable and essential role in encouraging many citizens to achieve social consciousness and action. He noted that about two-thirds of Americans embrace the belief that houses of worship contribute to solving critical social problems. Yasmin et al. (2014) pointed out that the terms "faithbased" and "religious charity organizations" are frequently used interchangeably and "are involved in activities that often are shaped by their faith" (p. 104). Clarke and Ware (2015) found that religious nongovernment organizations (RNGOs) in Australia, which are similar to RNPOs in the United States, are motivated by their missions and founded in religious and spiritual beliefs. Clarke and Ware (2015) argued that an intersection could be found between FBOs and RNPOs because both are informed by their religious teachings across a diverse spectrum of faiths.

Nevertheless, FBO organizations are classified as (a) faith-permeated organizations, (b) faith-centered organizations, (c) faith-affiliated organizations, and (d) faith-background organizations (Crofts, 2014; Sider \& Unruh, 2004). On one end of the faith continuum, RNPOs or FBOs are faith-infused entities requiring 
both participants and staff to sign or agree to a faith declaration explicitly. On the other end of the spectrum, RNPOs have a faith-centered background but do not require their staff or participants to commit to any religious activity. Faith background organizations only point to their origins, but the faith indoctrination in their delivery of service is not required. The religious diversity of RNPOs shows how complex they can be.

FBOs and RNPOs survival and existence are heavily dependent upon grants and donations of various stakeholders. In 2017, Americans gave over $\$ 400$ billion to religious organizations, education, human services, foundation health organizations, art, culture, humanities, and international affairs (Giving USA, 2018 ). Of the $\$ 400$ billion plus donated that year, $\$ 127$ billion, over $30 \%$, of all donations went to religious organizations. Further, individuals accounted for $70 \%$ of all donations, and corporations, foundations, and endowments gave the remaining 30\% of donations (Giving USA, 2018). Because of this, it is critical for RNPOs to strengthen their relationship with stakeholders, especially with individuals, because as Ramanath (2016) noted, annually at least half of all first-time donors to a Non-Governmental Organizations (NGO) or RNPO do not donate a second time; among repeat donors, it is not uncommon that the loss rates are as high as 30\% annually. The frequency or more particularly the infrequency of giving by donors makes vigilant governance and stewardship of RNPOs' funds critical to their survival and growth.

\section{Fraud in RNPOs}

There were approximately 1.56 to 1.9 million NPOs registered with the Internal Revenue Service (IRS) in 2015; those organizations contributed almost $\$ 1$ trillion to the U.S. economy that year, constituting 5.4\% of the country's gross domestic product (Donnelly, 2010; Tushe, 2016). Donnelly (2010) acknowledged that the IRS approves an average of 182 organizations every day. All organizations, including NPOs, are vulnerable to the threat of fraud (Harris et al., 2017; Stephens \& Flaherty, 2013). According to the ACFE, $10 \%$ of organizations that fell victim to fraud were NPOs (ACFE, 2019a).

Shaharuddin and Sulaiman (2015) suggested that even though religious organizations are regarded as 'sacred' and that people who worked there are perceived to have high moral values, the increase in financial scandals, like the misappropriation of funds amongst these institutions, are facilitated by poor accounting and internal control practices. They identified several factors that have contributed to fraud in RNPOs.

One impediment to effective accounting practices in RNPOS is the dichotomy between what is considered sacred and secular. Research does not altogether support the sacred versus secular divide as it pertains to accounting in RNPOs (Shaharuddin \& Sulaiman, 2015). Research suggests that some RNPOs prefer accounting activities to be undertaken by accountants with some religious connections. This differs from most religious NPO organizations. Another challenge within RNPOs is the significant trust afforded staff (Sulaiman et al., 2008). The absence of skepticism, and the presence of misplaced trust has created internal control problems in RNPOs. The lack of direct supervision has provided fraudsters the opportunity to victimize RNPOs (Shaharuddin \& Sulaiman, 2015).

Another factor within RNPOS that affects their ability to detect and deter fraud is the lack of involved "owners" (Shaharuddin \& Sulaiman, 2015). Unlike corporations and the other business models, RNPOs do not have financially interested stockholders or owners with an equity interest. Religious-based organizations generally lack transparency and accountability to their donors, some stakeholders, and the public (Shaharuddin \& Sulaiman, 2015).

Another contributor to fraud is the involvement of unskilled volunteers in RNPOs (Ventura \& Daniel, 2010). Ineffective accounting practices and weak internal controls exist in religious organizations because many volunteer treasurers are inadequately trained on accounting matters (Shaharuddin \& Sulaiman, 2015).

\section{Accounting for RNPOs}

Accounting practices in RNPOs may vary depending on the size, complexity and personnel expertise within each organization. Harris et al. (2017) found evidence that the more complex charitable organizations are, the more likely they are to experience internal control challenges. As a result, more complex charities encounter more substantial asset diversions. Harris et al. (2017) identified complexity as the number of "different revenue sources reported by the charity, including donations, government grants, and/or program service revenue (i.e., tuition, ticket sales, etc.)" (p. 156). Despite the size or complexity of 
the organization, various regulatory and accounting oversight bodies have outlined recommendations for effective accounting practices in NPOs.

Accounting departments should provide clarity to stakeholders, and strengthen NPO financial reporting, which include stopping or reducing fraud (Fitzsimons et al., 2018b). In 2016, the Financial Accounting Standards Board (FASB) implemented significant changes to the accounting policies for NPOs by issuing Accounting Standard Update (ASU) No. 2016-14, Not-for-Profit Entities (Topic 958): Presentation of Financial Statements of Not-for-Profit Entities (FASB,2016). These changes reduced some of the complexities of NPO reporting and improved the presentation of information related to liquidity, net assets, and financial performance. Abiding by these guidelines can contribute to decreased fraud.

FASB is not the only regulatory agency that proposed ideal accounting practices for NPOs. Harris et al. (2017) pointed out that the IRS requires NPOs or charities to disclose information about their awareness of any asset diversion and their governance structures. Also, the IRS requires tax-exempt charitable organizations that receive more than $\$ 25,000$ in revenue to complete IRS Form 990 . As part of this form, whether organizations are museums, churches, or trade unions, they must answer questions related to the size and independence of the organization's board of directors (BOD) and whether any significant changes have been made to the organization since the last filing of the Form 990 (Donnelly, 2010).

\section{Mitigating Tools}

Because of the misappropriation of hundreds of millions of dollars, transparency and accountability have become a necessity in the nonprofit sector (Geer et al., 2008). As previously discussed, leaders of RNPOs must heavily rely on fraud detection and deterrent tools to help them with the oversight of the organizations' financial resources and assets.

\section{Governance}

The ACFE identifies effective corporate governance as an essential factor to help prevent scandals and fraud. The results of Harris et al.'s (2017) study, using a sample of 764 charities that reported asset diversion from 2008 to 2012, indicated that if charitable entities had good governance, it would have mitigated the likelihood of misappropriated funds. Corporate governance refers to the policies and procedures according to which an organization is operated, regulated, and controlled. These processes are designed to protect the diverse interests of the organization's stakeholder groups.

There is also a principal-agent problem in NPOs; the interests of the principal and the agent do not align. Good governance includes the management of systems and processes to ensure the overall accountability, control, and directions of an organization. Bernstein et al. (2016) built on that viewpoint by noting that good governance places the burden on administrators to fulfill the legal and fiduciary responsibilities of an organization. These include: (a) oversight of programs and services; (b) financial, ethical, and legal oversight; (c) fundraising; (d) outreach setting the organization's mission and purpose; (e) selecting, supporting, and evaluating the chief executive; (f) strategic planning; and (g) recruiting of new board members.

The BOD serves as the primary governing body in NPOs and has the ultimate responsibility for the organization's mission (Jensen, 2003). Harris et al. (2017) reasoned that board or administrative oversight can mitigate the likelihood of asset diversions. Board monitoring involves regular oversight to ensure the organization has adequate resources and systems to provide accountability to its various stakeholders (Harris et al., 2017; Jensen, 2003). For example, periodic reviews of mission-related activities and financial reports enables leaders of RNPOs to detect potential problems sooner. Further, monitoring allows administrators in these organizations to determine if there are gaps in their internal control system.

However, governance structures in NPOs vary greatly. Some have different layers including the BOD, the CEO, and, in some cases, administrative leadership that can include volunteers. Whereas, in other cases, the pastors, imams, or the spiritual leaders serve dual roles as the administrative leaders of the RNPO, as well. Geer et al. (2008) acknowledged that some NPO administrators are uncertain about how to manage and develop accountability within their institutions. 


\section{Leadership}

Significant existing literature examines leadership styles. Sankaran et al. (2014) offered a working definition of leadership as a person's capability that transcends the standard scope of operational management to include a strategic capacity and the ability to deal with difficulty. The individual or individuals also has/have attributes such as innovation and vision, as well as a defensible confidence in using these attributes in an organizational role. Sankaran et al. (2014) identified capability as a necessity of good leadership as "mastery over a range of tasks or functions acquired through experience (professional and personal) and training (formal and informal)" (p. 556). Sankaran et al. (2014) suggested 'capability' is differentiated from 'competency' in that it is viewed as the ability to undertake a range of tasks or functions, whereas capability is seen as "a meta-competency that weaves the relevant competencies, experience and knowledge into a coherent set of behaviors" (p. 556).

RNPOs are top-down organizations that are run by pastors, imams, rabbis, and administrators with the purpose of carrying out a mission on behalf of multiple stakeholders. Each administrator adopts a specific leadership style, or a combination of leadership styles, to manage their entity (Bernstein et al., 2016; Thacker, Sullivan \& Self, 2019). The success of RNPO leaders' ability to detect and deter fraud in their organization hinges, in part, on the leadership style or combination of styles they adopt.

\section{Tone at the Top Leadership}

One model of organizational leadership is "tone at the top." The primary premise behind the tone at the top model suggests the overall culture and values from upper-level management and the BODs are thought to influence and promote ethical decision making by mid- and lower-level staff (Pickerd et al., 2015, p. 80; Schaubroeck et al., 2012). Pickerd et al. (2015) pointed out that because of the overwhelming anecdotal and empirical evidence, tone at the top construct is well recognized and embraced by business leaders, governments, professional organizations, and accounting researchers due to the fact that there is a strong correlation between that and financial reporting and operational benefits.

The tone at the top model is influenced by the self-concept maintenance construct, which suggests individuals are torn between competing stimuli. But in this model, people are sometimes caught between conflicting motivations (Pickerd et al., 2015). Mazar et al. (2008) continued that two variables determine what they call 'magnitude range of dishonesty'. The first is the degree of focus to an individuals' standards of conduct, such as religious norms; the second is the degree to which people categorize their actions into more likeminded terms and find explanations for their actions. Unethical behavior becomes acceptable in an organization to the point actions can be rationalized by employees and volunteers in the entity (Mazar et al., 2008; Pickerd et al., 2015). Leaders of RNPOs can help to deter fraud by setting an ethical tone.

\section{Competency-Based Leadership}

Due to their nature, RNPOs are more likely to be operated by novice volunteer administrators. As such, the degree to which leaders are competent directly relates to their ability to detect and deter fraud. Al-Halabi (2018) found in their study of Syrian banks that there was a positive relationship with trained leadership and the deterrence of accounting fraud.

The competency-based leadership construct was first described by Boyatzis (1982). An effective manager or leader is one who possesses certain competencies that enable them to attain success in their job. Success refers to desired outcomes (Boyatzis, 1982). Boyatzis (2008) expounded that there are three competencies superior performers possess. First, they have the emotional intelligence competency, or the ability to understand, recognize and use emotional information about themselves to produce superior performance. A second competency that outstanding performers possess is the cognitive intelligence competency, which is the ability to analyze information that produces effective performance. The third competency is social intelligence competency, which is the ability to discern and use emotional information about others that leads to superior performance.

Sanz and Fontrodona (2019), and Morales and Cabello (2015) provided a more contemporary perspective of many competencies in relation to cognitive skills, such as personal involvement, analytical capacity, teamwork, motivation, initiative, interpersonal skills, communication, and leadership. Sanz and 
Fontrodona (2019) continued that some of these competencies have a more moral overtone and individuals that possess them do not only contribute to the performance of a task, but primarily move the individual to a higher good and to a higher degree of fulfillment. Morales and Cabello (2015) asserted that moral competence can be defined as that skill set, knowledge, abilities, and attitudes attained through experience, which enable employees in the engagement of ethical behaviors in a specific job virtue. RNPOs that employ leaders who possess the above-mentioned competencies, especially the moral one, would most likely deter fraud because of the lens through which these leaders view their roles.

\section{Summary of Literature Review}

RNPOs are subject to the potential for fraud to a degree similar to other organizations, even though RNPOs embrace an overarching religious philosophical perspective that is integrated into the culture of their organizations. This study's researchers believe that good governance and proper leadership in RNPOs, the risk of fraud can be dramatically reduced. Further, internal controls and other fraud detection methods can help ensure accuracy in financial reporting, protect against the misappropriation of funds, and aid with compliance (Enofe \& Amaria, 2011). Fraud deterrent measures such as proper training on how to detect behavioral and financial red flags and training on codes of conduct and whistleblower policies can certainly be useful to administrators in denominational and non-denominational churches and other religious organizations in their attempts to curtail financial fraud (Enofe \& Amaria, 2011; Wells, 2013).

\section{RESEARCH DESIGN}

The purpose of this qualitative, multi-case study was to investigate accounting fraud in RNPOs throughout New Jersey, and to explore their ability to identify and implement adequate internal accounting controls to deter various forms of accounting fraud. Building on prior research that suggests that leadership or management styles influence the outcomes of organizations, especially when it relates to fraud detection and prevention (Patelli \& Pedrini, 2015; Schaubroeck et al., 2012; Bernstein et al., 2016), the researchers attempted to answer the RQ.

The multi-case method was adopted for this study because the researchers only sought to compare accounting fraud in RNPOs, fraud detection and deterrence over a limited period. The theoretical replication bolsters the validity of the research, and readers may view the study as more compelling. The researchers selected the multi-case design because, unlike single case studies that focus on one incidence, the multicase study allows the researchers to target multiple fraud episodes in RNPOs, comparing responses to determine if the participants share a similar perspective.

Yin (2014) suggests that case study research provides a robust basis for analysis and interpretation in the business environment because it is cradled in the natural environment of the phenomenon. The qualitative multiple case study method allows participants to answer open-ended questions, thereby allowing researchers to document variables that may go outside the hypothesis created in quantitative methods (Yin, 2014). This study certainly possesses many of these theoretical complexities. Yin (2014) also argued that a multi-case study is a design tool utilized by researchers to contribute to the knowledge of the phenomenon of organizations, individuals, or groups. The value of this study is that there has been little research on the role of leadership of RNPOs in detecting and deterring fraud.

\section{Sample}

In qualitative study, access to the 'right' participants is paramount to successful research (Nakhid, 2015). The researchers identified the types of participants who would best serve the research purposes, such as RNPO's accountants, financial stewards, church leaders, organization administrators, board members, committee members, pastors, rabbis, and imams, or anyone in the organization that had fiscal oversight.

The primary researcher has exposure to RNPOs in New Jersey and identified two sources for possibly identifying suitable participants. The first source was the New Jersey's Department of Consumer Affairs (DCA) registry of charitable organizations. The second source was a database of RNPOs provided by the 
Director of Strategic Alliance and Outreach of a faith-based college, where the primary researcher worked as an adjunct instructor.

The DCA, New Jersey's department that tracks charitable organizations, acknowledges there are over 4,000 charitable organizations registered in the New Jersey. Completing a study of all RNPOs in New Jersey would be cost prohibitive and extremely complex. Therefore, the researchers opted to incorporate purposeful qualitative sampling techniques in the study. Creswell (2015) maintains that qualitative sampling involves a few individuals and provides an in-depth understanding of the phenomena studied. Creswell and Poth (2018) found there are three characteristics of purposeful sampling: the sample size studied, the sampling strategy, and the participants.

The sample size in qualitative studies is vital to the legitimacy of the study. Sample adequacy in qualitative inquiry is an essential consideration in assessments of the trustworthiness and quality in addition to the appraisals of validity and generalizability of the study (Vasileiou et al., 2018). Vasileiou et al. (2018) and Baker and Edwards (2012) acknowledged that some critics of qualitative research contended that there is no definitive answer to the question of 'what is the ideal sample size,' but rather it is based on factors relating to epistemological, methodological, and practical issues. Nonetheless, most research authorities agree the valid standard for qualitative inquiry sample size happens at the saturation point. The saturation point is reached when obtaining additional data through interviews yields no new insights, no additional discoveries, no new data, no new themes, and no new codes (Creswell \& Poth, 2018; Vasileiou et al., 2018). Yin (2014) postulated that 6 to 10 is an adequate sample size for multiple case studies. Thus, the researchers applied this technique to the study.

To determine if an organization listed on the registry was active, the names were matched against online yellow and white pages. The second group of organizations available to the researcher came from a database of RNPOs. With the former group, the researcher determined that pointing out some of the pros and cons of detecting and deterring fraud in RNPOs may stimulate conversation and interest in the study. With the latter group, a personal introduction from the previously mentioned Director of Strategic Alliances and Outreach helped establish a relationship with participants and potentially reduced the anxiety that may have been associated with interviewing the leaders of these enterprises. In addition to face-to-face interviews, WebEx and Zoom were used due to their practical advantages, such as broader reach and the ability of pausing and stopping the interview (Smith et al., 2018).

Leaders of the selected RNPOs were assured that the research followed all ethical guidelines and was designed for protecting confidentiality and anonymity. In addition, all participants were given a nondisclosure and confidentiality agreement outlining the terms of the study to reduce anxiety and increase participants' comfort. To bolster participants' confidence, the primary researcher explained that after the interview was completed, any organization's identifying information would be removed and identifying organizational data deleted, so they could rest assured that their information was kept private.

The sampling strategy in involved the researcher using a multi-prong approach in which the researcher visited participants at their various places of operation, and secondly, utilized WebEx or Zoom interactive conferencing. The primary researcher interviewed financial administrators, rabbi, imams, pastors, or any organizational leader of RNPOs who may have an intimate knowledge of the accounting strategy of their organizations; it was more likely these people would understand their organization's financial system.

\section{Data Collection}

Qualitative researchers have many methods available to collect data. Regardless of the method chosen for any qualitative or quantitative study, the collection of high-quality data, along with the extraction and exploration of textual data to describe and explain the phenomena being researched is of paramount importance (Gelling, 2015). Pezalla et al. (2012) argued that researchers should conduct a semi-structured interview that facilitates conversation to create a safe and comfortable space in which the participants are willing to share information-rich data. They asserted that participants might experience a feeling of interpersonal connection with the interviewer, perhaps leading to more lengthy conversation and mutual understanding. After a rapport is established, one tool available to researchers in their quest to obtain meaningful insight during the interview process is an interview guide. Pedersen et al. (2016) described an 
interview guide as an instrument that helps ensure relevant questions, supports consistency between each case interview, and aids with linking the research questions, research problem, and past relevant literature.

Based on recommendations in prior research (Pedersen et al, 2016; Pezalla et al., 2012) the primary researcher in this study employed an interview guide to stay focused on the topic, and thoroughly examine the participants' knowledge of the subject. A comprehensive list of the 25 interview questions included in the interview guide is presented in Appendix A. The introductory statement of the interview guide acknowledged the importance of RNPOs role in society. The introduction noted that fraud could be detrimental for any RNPO because they are often held to a higher standard than other NPOs.

Questions 1, 3, 7, 9, 10, 13, 15, 17, 21, and 23 in the interview guide examined NPO staffs' formal and informal education, professional training, and occupational skills that empowered them to detect and deter fraud in their organizations. Items $2,11,12,14,16,17,18,19,20$, and 21 , were designed to determine if RNPO staff understood what internal controls were and whether they were in place in their organization. The closing statement of the interview guide indicated to leaders that their financial vigilance is critical to preventing fraud, despite hiring high-character personnel and volunteers in their organization.

To engage in the actual interviews, the primary researcher first created a list of email addresses and phone numbers of potential RNPOs that may want to participate in the interviewing process in Microsoft Excel. Initially, the researcher contacted 13 RNPO leaders, but only 10 were interested in participating an interview. This was an adequate number because the saturation point could occur at 10 participants (Yin, 2014). The researcher then grouped the RNPOs that were available for an in-person interview and those that were unable to conduct face-to-face interviews. For those that were unavailable for face-to-face interviews, the researcher used WebEx online software, which allows users to communicate virtually via computer video cameras. The intention was to meet face-to-face with those who were willing, but due to the COVID-19 pandemic and the suitability of recording the meetings, it was decided that all interviews would take place via the online platform. The researcher employed an electronic recorder and a writing pad to draft notes, as well as saving a digital recording of the video interview. The interviewer immediately transcribed the data after the interview to ensure none of the information was lost. The interviewer completed 10 interviews over a four-week period in January 2021. The saturation point occurred at the ninth interview, but the researcher did an additional interview to ensure no information was omitted.

In addition, the interviewer requested pertinent documentation from the RNPO leaders that might aid in the study, with the assurance that all documents would be destroyed upon completion of the study. The researcher requested that the documents be emailed to the primary interviewer's email address in a secure fashion. To further ensure the accuracy and reliability of the data, the primary research incorporated the member checking technique. Stake (2010) acknowledged that member checking, or the process of discussing the recorded draft with participants to determine if the data collected needs correction or any additional comments are necessary, contributes to the accuracy. After the interviews and member checking was completed, the primary researcher utilized NVivo coding software to transcribe and code data results into useful information for analysis.

\section{Data Analysis}

There are multiple techniques used to analyze data, but according to Simon and Goes (2013), there is no consensus on the best method for multi-case studies. However, Percy et al. (2015) pointed out that Stake (2010) and Creswell (2016) agreed, there are a few necessary steps associated with all data analysis. The first step was the descriptive step, in which in the primary researcher re-read the field notes that were collected during the interviews of the participants. The second step, direct interpretation, involved the researcher juxtaposing interviews and using pattern matching against the theoretical framework of the research in an attempt to determine if there were commonalities from each meeting. After finding commonalities, the interviewer then synthesized the data. Next, the primary researcher engaged in categorical aggregation, in which the researcher seeks to collect meaning rich occurrences from the data by putting it into specific categories of significance. The categories the researcher used to summarize the data were leadership competencies of governance, leadership understanding of fraud, and leadership 
understanding of internal controls. Finally, the use of the NVivo 12 software tool in the coding process enabled the interviewer to interpret and create naturalized generalizations from the data.

\section{RESULTS}

The fundamental goal of the researcher was to contribute to the body of literature about leaders' of RNPOs understanding of governance practices of their entities, the stewardship of their entities' assets, and tools, such as internal controls, that are available to them for detecting and deterring accounting fraud in their organizations. The results of the findings included a diverse collection of RNPOs: Three churches, a Christian health care center, a church mission that provides housing, education, and career services, a church training, daycare and pre-kindergarten service, an organization that provides music lessons to urban and suburban students, and one organization that operates as a cancer support program for women.

The RNPOs range from one employee to 729 employees. All the RNPOs were in the central and northern part of the New Jersey, perhaps because over $70 \%$ of the state's population lives in these two parts of New Jersey (NJ, 2019). Table 2 is a summary of the participants' demographic information, the size of the entities' budgets, and size of the entities' staffs.

The researchers summarized the universal background information about each RNPO leader for two reasons. First, to determine if there was a correlation between the leaders' backgrounds, preparing them in full or in part, to detect fraud in their enterprises. Second, the researchers did so to allow for pattern matching between leaders. The basic information about the leaders' backgrounds included the gender, age, formal education, type of leadership role in the RNPO, the period in that leadership role, and whether each participant was paid or a volunteer.

\section{Gender and Age}

The basic information revealed that there were precisely $50 \%$ male and female participants (see Table 2). Another variable this study considered was the age of interviewees. To reduce the anxiety and protect participants' anonymity, the researcher collected age ranges versus the exact age, even though four of the participants provided their precise age. Pezalla et al. (2012) contended that interviewers should facilitate the interview to create a conversational safe and comfortable space where the participants are willing to share information-rich data after establishing a connection with interviewers.

The age groups used in the research study are: (30-39), (40-49), (50-59), and 60+. The ages of participants were distributed as follows:

- 3 RNPO leaders $(30.0 \%)-30-39$ age range

- 2 RNPO leaders $(20.0 \%)-40-49$ age range

- 2 RNPO leaders $(20.0 \%)-50-59$ age range

- 3 RNPO leaders $(30.0 \%)-60+$ age range

The research findings showed the age range was almost evenly distributed. After examining the two variables of gender and age with respect to leaders in this research study, the researcher concluded that the findings did not indicate staffs' ability to detect and deter fraud in their organizations. Reflecting on the research question, there was no conclusive patterns to determine if age or gender made a difference in the deterrence and detection of fraud in RNPOs. This may be an opportunity for future research.

\section{Formal Higher Education}

Data about the RNPOs leaders' formal, higher educational accomplishments was gathered. The higher educational achievement for the participants included:

- 1 RNPO leader - $(20.0 \%)$ Doctorate

- 6 RNPO leaders - $(60.0 \%)$ Master

- 1 RNPO leader - (10.0\%) Bachelor

- 2 RNPO leaders - (20.0\%) Some College 
The researchers examined the higher educational level of RNPO staff to determine if there was a relationship between the leaders' education and their ability to comprehend accounting and financial information. Education conveys valuable skills and knowledge, assisting employees with the underlying ability to perform their jobs efficiently and knowledgeably (Toner \& Woolley, 2016; Wolfe \& Hermanson, 2004). Harris et al. (2017) pointed out that some NPO staff are amateurs in governance positions in the stewardship. Further, Steimel (2018) purported that often volunteers obtain little job training and many times are not credentialed to perform the expected tasks.

The data in this study contradict some prior study because at least $80 \%$ of employees (volunteer and paid staff), had a bachelor's degree or higher. Additionally, this study contradicts some previous findings in that $30 \%$ of the RNPO participants had a bachelor's or master's degree in business administration and were in their role an average of nine years.

However, the study not find significant evidence to support formal higher education by itself as a determinant of whether a participant understood internal accounting controls in the detection and deterrence of fraud. The results support one previous study that suggested the NPO sector has progressed from the novices and volunteer staffing model to a more highly formalized staffing structure of subject matter experts, professional managers, and cost accountants (Feng et al., 2019).

TABLE 2

DEMOGRAPHICS OF PARTICIPANTS AND SIZE OF ORGANIZATION

\begin{tabular}{lllllll}
\hline Participants & $\begin{array}{l}\text { Age } \\
\text { Range }\end{array}$ & Gender & $\begin{array}{l}\text { Years of } \\
\text { Experience }\end{array}$ & $\begin{array}{l}\text { Educational } \\
\text { Level }\end{array}$ & $\begin{array}{l}\text { Organizations } \\
\text { Annual Budget }\end{array}$ & $\begin{array}{l}\text { Organizations } \\
\text { Staff size }\end{array}$ \\
\hline 1 & $30-39$ & Male & 3.5 & Master & $\$ 150,000$ & $5-12$ volunteers \\
2 & $50-59$ & Female & 4 & Some college & $\begin{array}{l}\$ 20,000 \\
\text { Master }\end{array}$ & $\begin{array}{l}\text { \$2.75 million } \\
75-80 \text { total }\end{array}$ \\
3 & $60+$ & Male & 3.5 & Manteers \\
4 & $30-39$ & Female & 4 & Master & $\$ 18,400$ & 15 volunteers \\
5 & $40-49$ & Female & 12 & Master & $\$ 16,000$ & 1 stipend \\
6 & $40-49$ & Male & 1 & Some college & $\$ 500,000$ & 1 paid \\
7 & $50-59$ & Male & 30 & Master & $\$ 80$ million & 729 paid \\
8 & $30-39$ & Male & 5 & Bachelors & $\$ 265,000$ & 5 paid \\
9 & $60+$ & Female & 20 & Masters & $\$ 7$ to $\$ 10,000$ & $6-8$ volunteers \\
10 & $60+$ & Female & 5 & PhD & $\$ 25,000$ & PhD \\
\hline
\end{tabular}

\section{Accounting Education or Experience}

The researchers determined if the participants had specific accounting education and experience that contributed to their ability to identify and deter fraud. Avey et al. (2008) identified the leadership competency model as abilities, skills, knowledge, and other attributes that are relevant for a leader's success in a particular job, or as identified in this study, religious leaders' ability to successfully deter accounting fraud. Thirty-percent of respondents said they had no accounting education and accounting experience as the organization's administrator in understanding internal financial controls. Twenty-percent of interviewees had some accounting knowledge, but relied heavily on someone else to oversee the internal accounting controls. One of the respondents understood internal controls from a functional responsibility; she understood that excellent accounting practices require two people to sign checks and others to deposit funds, thus creating a separation of duties and responsibilities. However, that participant had no formal accounting training. Two were former financial administrators or a chief financial officer of organizations with a thorough understanding of internal accounting controls. One participant only had one college accounting class, and one received only on-the-job experience in their understanding of internal controls.

This study contradicts the previous finding in that $30 \%$ of the participants had master's degrees coupled with experience as financial administrators and a CPA, making them capable academically and occupationally able to detect and deter fraud in their enterprises. Another part of Question 1 in the interview 
guide asked participants if they had any financial or accounting certification, such as Certified Public Accountant or Certified Financial Planner designation. Only one interviewee was a CPA.

Participant 7 stated, "I believe that being trained as a CPA and sitting on audit committees has empowered me to properly manage the detection and deterrence of fraud in my organizations." Participant 10 had a Ph.D. and an MBA and stated that even though they earned an MBA, which included some accounting education, the NPO had no internal controls to detect or deter fraud. She continued that after the interview, she saw the importance of having them in place. Participant 8, who has a bachelor's degree, stated he does not believe in being a jack-of-all-trades and master of none. He went on to state 'he believes in hiring people who are content experts in their area.' He continued that he has pastored three churches, and the first thing he examines when he starts his tenure at a new church is accounts and financial statements. He has used a reputable CPA for several years, and he has used them to complete a forensic examination of the financial statements of each church he has pastored.

Gratton (2018) found that employees and volunteers at NPOs often lack the fundamental human resources skills and experience their for-profit equivalents possess. Current study contradicts some of the traditional viewpoints in that RNPOs showed that $80 \%$ of participants had at least a bachelor's degree, and $20 \%$ of the leaders had significant experience as a CFO and another as a financial administrator. The findings show that participants' perspectives were the driver of the importance of internal accounting controls (Ventura \& Daniel, 2010). This study refutes some previous studies because at least $20 \%$ had significant accounting experience and understanding of how to detect and deter fraud in their organizations. In addition, $30 \%$ had at least some accounting training or experience in understanding accounting practices.

\section{Volunteerism Versus Paid Employment}

Another interest to the researchers in the fact-finding process in answering the RQ was whether the interviewees were paid or were volunteers inside and/or outside of their organization. Questions 3 and 4 of the interview guide in Table 3 indicates results of participants' work experience.

Fifty percent of the participants were partially or fully paid employees of their organization, and the other five or $50 \%$ were volunteers. Forty percent of the interviewees were both founders and volunteers of their organizations. Only one volunteer or $10 \%$ of the participants was not the founder of their organization or had a full-time position in their RNPOs. Erasmus and Morey (2016) noted that faith-based nonprofit organizations usually have a higher number of volunteers relative to other forms of not profit organization. The finding in this study showed it all depended on the organization's staff and budget size. The results show the relatively larger organizations paid their leaders. Larger organizations are more likely to have greater capacity to implement strategies that ensure access to vital resources such as critical staffing for survival and growth of the organization (Davis \& Cobb, 2009; Del Mar et al., 2016). Perhaps because these entities received more income and had more staff, they had much more to preserve. The findings of this study indicate that RNPOs that had paid leaders in turn had better internal controls in place.

\section{Professional and Non-Professional Experience}

The researcher asked RNPO leaders about how their professional or non-professional experience equipped them to detect potential fraud, mismanagement, misappropriation, or abuse in their religious entities. Eraut (2004) found in their research that meaningful learning experiences do happen outside of the formal education institutions. Some learning happens in families, workplaces, and other organizations or institutional settings. All participants said they believe either their professional or non-professional experience had equipped them to detect fraud. Some skills are not developed in a formal setting, but some skills are developed on the job. Informal learning in many occasions is said to be more effective for learning job-related skills and competencies than traditional education (Eraut, 2004; Schürmann \& Beausaert, 2016).

The interviewees provided the following about their various perceptions. Participant 4 stated she did not have any professional experience deterring or detecting fraud, but her non-professional experience through lived cultural experiences has aided her in detecting fraud. She also said all the funds received in her organization go through her, and recipients of the monies sent overseas need to provide receipts for any expenditures. Participant 7 posited his professional experience working for a major accounting firm for 
seven years and then as the chief financial officer for four years and the chief executive officer for another 26 years had aided him in detecting and deterring fraud in his organization. Participant 1 expressed that his professional and non-professional experience of creating hard copies and digital copies of all financial and accounting transactions has equipped him to deter financial abuse in his organization. One-hundred percent $(100 \%)$ of the RNPOs leaders perceived their professional and non-professional experience in and outside of their organization had enabled them to detect and deter fraud in their entities.

\section{TABLE 3 RESPONSES TO QUESTIONS 3 AND 4}

\begin{tabular}{lll}
\hline & Position outside RNPO & Position in RNPO \\
\hline Participant 1 & Partnership coordinator & Director \\
Participant 2 & Part time home care & Administrator \\
Participant 3 & None & Director \\
Participant 4 & Teacher & Director \\
Participant 5 & Self-employed music teacher & Director \\
Participant 6 & None & Director \\
Participant 7 & None & CEO \\
Participant 8 & None & Pastor \\
Participant 9 & Childcare center director & Director \\
Participant 10 & Professor & Pastor \\
\hline
\end{tabular}

\section{Financial Decisions}

Next, the researcher used Questions 5, 6, and 10 to establish if participants have made financial decisions on behalf of their organization and how long they have done so. These questions were asked to determine if the leaders selected were involved in making fiscal determinations on behalf of their entities. Ninety percent (90\%) of leaders said they provided financial management support for their organizations. Only Participant 9 stated that someone else is entrusted with financial management support on behalf of the organization. Seventy percent $(70 \%)$ or 7 of 10 of the leaders have made financial decisions for their organizations between 1 year and 5 years, and the additional $30 \%$ of leaders have made financial decisions for 12,20 , and 30 years, respectively.

Forty percent $(40 \%)$ of interviewees make all their enterprises' financial decisions. Participant 3 expressed his home office makes most of the financial decisions. He said he makes some local financial decisions. Participant 5 stated she is involved in decisions pertaining to the expansion of the organization. I also have to approve and ask the treasurer to accept it. They include multiple board members in counting cash. Overall, $90 \%$ of RNPO leaders make financial decisions either partially or totally on behalf of their entity. This question was asked to ascertain the degree of financial involvement of leaders in their organizations' financial decision-making.

\section{Fiduciary Responsibility}

All respondents answered Question 9 that the BOD, and/or the pastor, and/or director, and/or administrators have the fiduciary oversight of the organization's resources. The researchers incorporated the question to determine the administrators' perspective concerning who was responsible for the fiduciary responsibly for protecting the organization's resources.

Rae et al. (2017) and Treadway Commission Report COSO (2017) noted the reliability of financial reports along with all other components of internal control hinges on the 'tone at the top' of an organization. Warren et al. (2015) opined that the tone at top theory is broadly accepted as one of the primary predictors of ethical behavior in organizations. McKay and Maboya (2019) pointed out that one item on the leadership minds of the NPOs is having the skills and capacity to adequately managing the organization's finances and board oversight. The unanimous RNPOs perspective validates prior research that leaderships are profoundly concerned about protecting their organization's resources. 


\section{Additional Training}

To better understand Research Question 1, the researcher asked Question 13 of the interview guide, 'What additional training is required for you to strengthen your financial competencies to adequately safeguard the organization's resources? Ninety percent of the interviewees said they needed some training. Participant 9 stated she believes she needed training because things are continually changing. Participant 5 stated given who her treasurer is, she does not believe she needs any training. She went on to assert her treasurer is an accounting guru. Participant 7 said one of the things he was most concerned about was cybersecurity. He said the use of technology had created some unintended consequences about which he is worried, and getting trained in those facets is what he would like.

Thomson et al. (2016) acknowledged that respondents of a one-year leadership training expressed that the ongoing training had 'very much' improved their ability to understand the results and they were able to complete an analysis. Overwhelmingly, leaders believe there was need to gain additional training because of the changing environment and their lack of adequate understanding of fraud in their organizations.

\section{Summary of the Findings}

This multi-case qualitative study explored if there was a relationship between leadership competence, leadership style, and the ability to detect fraud in RNPOs leaders. Overall, the general findings showed 10 diverse New Jersey RNPOs with highly educated leaders. The RNPOs staff sizes ranged from one person to 727 people. Their budgets ranged from $\$ 7,000$ to $\$ 80$ million.

There are a few revelations of the study that either refuted previous studies or confirmed other studies. This study revealed that $80 \%$ of all leaders had a bachelor's degree or higher. In fact, $70 \%$ had at least a master's degree. However, there was no conclusive evidence pointing towards that higher education by itself enables RNPO leaders to detect and deter fraud in their organizations.

However, after delving more in-depth, the study found $30 \%$ had obtained both specific higher education and/or experience on their job that prepared them to implement sound internal controls to detect and deter fraud. The finding also confirmed previous research that larger organizations are more likely to have a greater capacity to implement strategies that ensure access to vital resources such as critical staffing for survival and growth of the organization (Davis \& Cobb, 2009; Del Mar Gálvez-Rodríguez et al., 2016). The organization with relatively larger budgets and staff had paid leaders with more robust internal controls in place. Unanimously, all leaders believed they were responsible for the fiduciary oversight of their respective organization's resources. However, they all thought they needed training to get a better grasp of various financial and accounting issues that may influence their organizations.

\section{Applications to Professional Practice}

Current study can contribute to professional practice by adding to the existing body of literature about the inability of leaders of RNPOs in New Jersey to identify and implement adequate accounting internal controls to detect and deter accounting fraud. Albrecht et al. (2015) cited that financial statement fraud is ordinarily a top-down type of fraud that adversely influences individuals, organizations, and society. Previous studies identified that detecting and deterring fraud in NPOs should not be a secondary process, but an integral part of operations. The discovery of fraud often is costly and can have serious ramifications, possibly crippling an organization and potentially causing some entities to fail (Said et al., 2018).

Considering these threats, the first topic that this multi-case qualitative study brings explores is the necessity for RNPOs founders, BOD, and leaders to craft awareness and perception in their organizations' management and staff that the threat of fraud exists. After creating the awareness of fraud, management needs to provide recommendations and mechanisms to detect and deter it. In this study, many leaders did not consider the danger of fraud in their organization. Sixty percent $(60 \%)$ of respondents said they did not believe they adequately protected their enterprises against fraud. Participant 10 of the study who holds a $\mathrm{Ph} . \mathrm{D}$. and MBA stated, "There is a lot of work that I need to do because I never consider issues surrounding fraud in my organization." Participant 4 said that the interview was "eye-opening," meaning she did not consider the threat of fraud in her organization. 
In addition, $70 \%$ of RNPOs acknowledge they have nothing to deal with fraud potentially committed by leaders. The necessity of improving RNPOs leadership awareness can reduce its susceptibility to fraud schemes by implementing robust internal accounting controls to mitigate deficiencies. RNPOs can create and enhance the segregation of duties and develop inexperienced leaders and staff to devote the necessary resources to accounting functions (Gartland, 2016). This study revealed there is a lack of awareness and the need to educate RNPOs leaders about the implication of fraud in organizations.

Another finding identified in this study that can close gaps in fraud deterrence and detection in RNPOs is the use of trained financial professionals or CPAs. Seventy percent $(70 \%)$ of respondents of the study expressed their organization has never done a risk assessment. Also, $70 \%$ or 7 out of the 10 leaders said they do not understand GAAP or FASBs regulations. Thousands of CPAs work in the not-for-profit sector, and thousands more volunteer as members of the governing boards of nonprofit organizations (Cashwell et al., 2019). CPAs and accountants provide valuable services because they inspect financial records to determine what story the financial records communicate to all stakeholders.

Besides laboriously going through financial records, CPAs and financial professionals perform risk assessments for RNPOs and other organizations to assist them in tightening their internal controls and identifying red flags in employees and financial records. Kummer et al. (2015) opined in their research that entities often use specific fraud assessment instruments and will find there are assortments of fraud detection and prevention tools available to them. Only 30\% of the RNPOs in this study have ever done a risk assessment. A risk assessment would educate leaders how to start closing potential opportunities for would-be fraudsters. Also, trained professionals like CPAs can conduct a risk assessment. External CPA firms are also a valuable resource for conducting risk assessments to determine if an RNPO needs to invest a small or an extensive amount of resources in strengthening its current efforts against fraud.

The third significant finding this study revealed was leaders' need of ongoing training. Unlike professions like CPAs and attorneys, RNPO leaders do not have to take continuing education classes to maintain a professional license. Ongoing professional development is optional. Overwhelmingly, most of the RNPOs leaders in this study acknowledged the need for training about fraud, not-for-profit taxes, and cybersecurity pertain to their accounting and financial processes. Hauser (2019) suggested that employees' regular training is one of the most effective ways of preventing corruption. He continued in his argument that training must be specific to confront challenging questions regarding ambiguities of ethics and compliance. Thus, training can be a low-cost part of RNPOs' fight against fraud. In sum, the implementation of mechanisms to raise fraud awareness, hiring CPAs or financial professionals, and completing a risk assessment and training employees can aid RNPOs in their plight of guarding God's precious resources.

\section{Recommendations for Action}

Throughout this study it became apparent to the researcher there are very few differences between RNPOs and NPO or for-profit organizations financially. The only thing that distinguishes RNPOs is the underlying tenets of faith that are subtly or noticeably interwoven in their mission and daily operations. Yasmin et al. (2014) opined that RNPOs are churches, nonprofit employers, civic organizations, or any organizations that hold some type of religious underpinning or faith in their core beliefs. In this research, RNPOs could incorporate if not already applied in their organization the following best practices.

- Raising fraud awareness

- Engaging a CPA or qualified financial profession to audit financial statements annually

- The creation of a fraud policy

- Require all administrators and key staff to attend annual or monthly training

- The annual review of financial policies with key members of staff.

\section{Raising Fraud Awareness}

Participant 10, who had a Ph.D. and an MBA, stated that even though she had an MBA, which included some accounting education, she did not have any internal controls. She went on to express during our interview, she did not see the importance of having internal controls until after our interview. Creating 
awareness in RNPOs leadership is of extreme importance in the detection and deterring fraud. Fraud awareness should not be trivial, but ethical examples set by the administration within an organization will influence members' awareness of, and attitudes toward, codes of ethics, including fraud (Gates et al., 2016). Continuous impromptu independent checks and balances can also serve as a psychological deterrent to perpetrators that everyone is being considered on an interval basis. McMahon et al. (2016) suggested that the creation of a checks and balances system designed to ensure executives and employees are vigilant in an organization tactics of fighting financial crimes.

\section{Engaging a CPA}

To strengthen RNPOs financial statements and promote effective accounting practices, including strong internal controls, RNPOs could employ the services of a CPA. One way to create awareness is to hire a CPA to discuss the implications of fraud with RNPOs leaders, especially the BOD. Two of the interviewees stated they would like to hire a CPA, but they did not have the funds. However, one of the most inexpensive ways to get an accountant or CPA is to elect one on the organization's BOD (Harris et al., 2017). Jensen (1993) posited that the BOD is the apex of the governance structure and as having ultimate responsibility for the effectiveness of the organization in which it serves (Harris et al., 2017). Besides electing a CPA or financial professional on the BOD, some CPAs volunteer their services to NPOs, including religious ones. Shafer et al. (2016) pointed out that some CPAs provide pro-bono accounting services through not-forprofit groups such as Accountants for the Public Interest (API). API is a nonprofit organization whose emphasis is to encourage accountants to volunteer their time and expertise to individuals, small businesses, and nonprofits, that cannot afford professional accounting services.

\section{The Creation of a Fraud Policy}

Another best practice that RNPOs could consider in their effort to bolster their detection and deterrence is creating a fraud policy. A RNPO can create a comprehensive written fraud policy that all employees and volunteers sign at the start of their employment. Tiwari and Debnath (2017) found framing organizationallevel policies such as a fraud policy that requires written acknowledgement from employees and volunteers that they have read and understood the clauses can be an effective fraud deterrent. Having each employee sign a written policy that they may be imprisoned can be a psychological deterrent in the mind of fraudsters. One way that RNPO leaders can design a fraud policy is by consulting with a financial professional or CPA. Apart from providing auditing services, CPA firms provide consultation services such as completing a risk assessment of internal controls and developing fraud policies. Besides that, leaders in these organizations could refer to accounting groups such as the association of fraud examiners (ACFE), which usually publish the Small Business Fraud Prevention Manuals. These manuals have samples of fraud policies and code of ethics that leaders of RNPOs can glean form to develop their fraud policies (Anders, 2020).

RNPOs could collaborate and become members of recognized organizations that may have a fraud policy template. Organizations like the Evangelical Christian Financial Accountability (ECFA) can provide RNPOs with significant resources in developing their fraud policy. To give credibility to stakeholders (ECFA), RNPO can implement ECFA guidelines, and ECFA's Seven Standards of Responsible Stewardship (ECFA, 2020).

One best practice that RNPOs can adopted is training personnel. One need indicated by all the interviewees is the need for training. Campa (2018) found there is a direct correlation between the existence of fraud training and the reduction of financial statement manipulation. Training the BOD, managers, and key personnel using workshops and seminars on the topic of fraud on a monthly quarter basis, but at least an annual can assist RNPOs in their plight to counteract fraud in their organization. Competent personnel can do internal training about the subject of fraud incorporating Biblical or religious context because most religions do not condone theft.

If the organization does not have the resources to conduct internal training, they can use local face-toface workshops, or seminars led by larger organizations in their sector or accounting associations such as ACFE. Training can include webinars or online or digital tools. Whether RNPOs do internal training, 
online, or by external entity research shows that having some fraud training helps mitigate challenges that organizations incur when protecting valuable resources.

\section{Annual Review of Financial Policies}

The final recommended best practice is to review fraud policies with staff at least annually to determine its effectiveness and appropriateness. With the constant changes in the business environment, systems need to be revised from time to time to see if it is current and useful. Essential personnel can set aside time revisiting fraud policies examining the data, exchanging ideas of what changes need to be made and creating strategies to make it current and useful. Prudent RNPO leaders can implement fraud awareness training among its staff and volunteers. RNPOs leader can engage a CPA to assist with developing fraud policies. Requiring key personnel to obtain fraud training and reviewing its fraud policy annually to make their businesses better in the deterrence and detection of fraud. Based on the respondents' feedback, the researcher determined that RNPOs can adopt all or some of the suggestions as best practices.

\section{Recommendations for Further Study}

There are opportunities to expand the study of the inability of leaders of religious not-for-profit organizations in New Jersey to identify and implement adequate accounting internal controls to detect and deter accounting fraud. Incidentally, all the RNPOs interviewed were philosophically Christian. One recommendation for further study for other researchers to explore is they could focus on diverse religious NPO such as Sikhs, Hindus, Jews, and Muslims. Awang (2019) researched "fraud in financial reporting among Muslim participants" (p. 771) and demonstrates that fraud does not discriminate against the type of religious organizations affected.

Another idea for other researchers to expand on this research is to expand it to different geographic regions. The researcher could replicate this study in another state in the United States of America or even other countries outside of the United States, such as Canada, the United Kingdom, or China. Because of the globalization of economies, some issues such as fraud in RNPOs may creep into other societies. Malaysia, as an emerging country with a make-up of people of various religious persuasion and ethnic origin, is not without financial fraud (Nasir et al., 2019). So, replicating this study in another geographic region may benefit the population in that area.

Additional research may include a quantitative version of this study. This study investigated a multicase study qualitative viewpoint of the inability of leaders in RNPOs to identify and implement adequate accounting controls. Quantitative studies can produce different result because it involves a larger sample. Creswell (2015) pointed out that quantitative research is more narrowly focused on variables and examines a sample with the intent to generalize from the sample.

Future research can examine the relationship between unorthodox accounting practices and fraud in religious not-for-profit organizations. Not all RNPOs may follow General Accepted Accounting Principles (GAAP) or Financial Accounting Standards Board (FASB) internal accounting documents, practices, or operational processes. An organization may have adopted unorthodox accounting practices. Xu et al. (2016) reported between the period between 1986 and 1997, the use of a non-GAAP system of measurement sharply increased in the United States. A researcher may consider the use of non- GAAP methods used by RNPOs and its relationship to fraud.

An additional recommendation for further research is the use of other methods of protecting the organization's assets. In recent years, organizations have implemented management information systems to act as the proverbial sixth man in their fight against fraud. Many organizations promote paying electronically via PayPal and Cash app, both electronic management information payment systems. Some technologically savvy fraudsters may find a way to divert funds using these payment methods to their personal accounts. Segal (2016) pointed out that the explosion of computer-based resources opened the portal for a new kind of computer-based accounting fraud. A researcher may provide valuable information on how to assist organizations in diminish fraud that may occur in RNPOs.

The last topic that other researchers may be interested in exploring is how RNPOs can strengthen their internal controls is already in place against external fraud risk and fraud committed solely by management. 
One variable in Cressey's fraud triangle theory is the opportunity. Management often time are in ideal positions to take advantage of RNPOs. Zuberi and Siasa (2019) acknowledged that not for profits encounter internal criminological factors management collusion with third-party vendors and management internal control overrides. A study examining whether RNPOs have adequate internal controls to deal with managerial fraud could be considered.

\section{CONCLUSION}

This multi-case qualitative study of the inability of leaders of RNPOs in the New Jersey to identify and implement adequate accounting internal controls to detect and deter accounting fraud was crafted to add to the limited body of literature on the subject. Archambeault and Webber (2018) opined there is a deficiency of accurate data on the consequences of fraud in NPOs and RNPOs. The reality is fraud affects all organizations, even those that have religiosity at their core or sprinkled into their mission.

This multi-case qualitative study incorporated interviews with 10 diverse RNPO leaders in New Jersey concerning leadership competence, perception, leadership style, and mechanisms or internal accounting controls they had in place to prevent accounting fraud. The findings of the study both refuted and bolsters previous research. The findings of this study showed a highly educated group of leaders with $80 \%$ attaining a bachelor's degree or higher. Moreover, out of the $80 \%, 30 \%$ held a bachelor's or master's in business administration and/or CPA designation. Further, 2 or $20 \%$ of the $80 \%$ were either a financial administrator or CFO in their careers. Additional, 3 or $30 \%$ of the research respondents had a bachelor's or master's degree in business administration with credits in accounting. This finding refutes some previous research.

Another finding this study refuted is Harris et al. (2017), who suggested there are amateurs in positions of governance in the stewardship of NPOs. This study showed the average amount of time each of the RNPOs leaders was employed in a leadership position in their organization was $50 \%$, including both partially and fully paid employees. In part, this contradicted a previous study that reported that many smaller NPOs may not have the relevant expertise and resources to prevent fraud (Kummer et al., 2015).

One finding that validates previous studies is the need for specific and ongoing training. Overwhelmingly $90 \%$ or nine out of the participants interviewed indicated they needed additional training for various reasons. This finding supports previous findings. Hauser (2019) suggested that regular training of employees is one of the most effective ways of preventing corruption. Der Wal et al. (2016) opined NPOs would not benefit from various types of integrity and ethics training, unless it is targeted. Other than a former CFO and a former financial administrators who were already familiar with GAAP and FASB, the other participants were eager to obtain additional training to better secure their organizations' resources.

One of the discoveries in this study was the difference in perspective of fraud and internal controls. There were diametrically opposite opinions and perspectives, primarily based on organizations' budget and size. One interviewee stated that the interview process was "an eye-opening experience." Another respondent, the highest educated with an MBA and Ph.D., stated her perception of fraud was she did not see the importance of internal controls. Another interviewee also stated she did not see the importance of internal controls in her organization because her organization did not have a significant budget. However, the former CPA stated his organization had a robust internal control system and protecting his organization's assets was extremely important. However, there were two outliers to the summary of fraud awareness. These local entities had parent organizations that had healthy oversight of the local chapters' budget and finances. Based on the on the findings, it was clear that raising fraud awareness among RNPO leaders was essential in detecting and deterring fraud.

As it pertains to how the leaders felt about their organizations ability to protect against fraud, $60 \%$ of respondents stated they did not feel they were protected against fraud. Again, fraud was not a tremendous consideration in the operations of these RNPOs. To aid practitioners, the study identified recommendations for action. The first was creating a fraud awareness program in their organization by having employees sign the RNPOs fraud policy upon hire. Another suggestion was engaging a CPA by either employing one on the BOD or hiring one or reaching out to CPA societies to get one through volunteerism. Two lesser, but equally important recommendations, were creating a fraud policy and conducting at least annual training 
with key employee and volunteers. Many RNPOs have selfless, ethical staff. However, RNPO leaders must remain aware of the potential fraud threats to their organizations.

\section{REFERENCES}

Albrecht, C., Holland, D., Malagueño, R., Dolan, S., \& Tzafrir, S. (2015). The role of power in financial statement fraud schemes. Journal of Business Ethics, 131(4), 803-813.

Al-Halabi, N.B. (2018). The impact of applying modern financial analysis tools on detecting fraudulent practices in financial statements of listed banks - An analytical study. Pertanika Journal of Social Sciences \& Humanities, 26(4), 2599-2612.

Anders, S.B. (2020). ACFE and ABFA Fraud Resources. CPA Journal, 90(3), 62-63.

Archambeault, D.S., \& Webber, S. (2018). Fraud survival in nonprofit organizations: Empirical evidence. Nonprofit Management and Leadership, 29(1), 29-46.

Archambeault, D.S., Webber, S., \& Greenlee, J. (2015). Fraud and corruption in U.S. nonprofit entities. $A$ Summary of Press Reports 2008-2011, 44(6), 1194-1224

Association of Certified Fraud Examiners. (2019a). Fraud resources. Retrieved from https://www.acfe.com/fraud-101.aspx

Association of Certified Fraud Examiners. (2019b). Fighting Fraud in Government. Retrieved from https://www.acfe.com/uploadedFiles/Shared_Content/Products/Self-

Study_CPE/Fighting\%20Fraud_Chapter.pdf

Association of Certified Fraud Examiners. (2020). Retrieved https://acfepublic.s3-us-west2.amazonaws.com/2020-Report-to-the-Nations.pdf

Avey, J.B., Hughes, L.W., Norman, S.M., \& Luthans, K.W. (2008). Using positivity, transformational leadership and empowerment to combat employee negativity. Leadership \& Organization Development Journal, 29(2), 110-126.

Awang, Y. (2019). The influences of attitude, subjective norm and adherence to Islamic professional ethics on fraud intention in financial reporting. Journal of Islamic Accounting and Business Research, 10(5), 710-725.

Backer, J. (2016). Thou shalt not electioneer religious nonprofit political activity and the threat "God pacs" pose to democracy and religion. Michigan Law Review, 114(4), 619-648.

Baker, S.E., \& Edwards, R. (2012). How many qualitative interviews is enough? Expert voices and early career reflections on sampling and cases in qualitative research. National Centre for Research Methods Review Paper. Retrieved from http://eprints.ncrm.ac.uk/2273/4/how_many_interviews.pdf

Bernstein, R., Buse K., \& Bilimoria, D. (2016). Revisiting agency and stewardship theories: Perspectives from nonprofit board chairs and CEOs. Nonprofit Management and Leadership, 26(4), 489-498.

Boyatzis, R. (1982). The competent manager. A model for effective performance. Retrieved from https://www.researchgate.net/publication/247813294_The_Competent_Manager_A_Model_For_ Effective_Performance

Boyatzis, R. (Ed.). (2008). Competencies in the 21st century: Competencies in the 21st century. Retrieved from https://ebookcentral-proquest-com.ezproxy.liberty.edu

Campa, D. (2018). Regulatory enforcement and the effectiveness of fraud training: A European investigation into earnings manipulation. Comptabilité Contrôle Audit, 24(1), 81-111.

Cashwell, K., Copley, P., \& Dugan, M. (2019). Using ratio analysis to manage not-for-profit organizations. CPA Journal, 89(5), 52-57.

Clarke, M., \& Ware, V.A. (2015). Understanding faith-based organizations: How FBOs are contrasted with NGOs in international development literature. Progress in Development Studies, 15(1), 37 48.

Committee of Sponsoring Organizations of the Treadway Commission (COSO). (2017). Report of the national commission on fraudulent financial reporting. Retrieved August 2020, from http://www.Coso.org/Publications/NCFFR.pdf 
Creswell, J.W. (2015). Research design: Qualitative, quantitative, and mixed methods approaches (4th ed.). Sage.

Creswell, J.W. (2016). 30 essential skills for the qualitative researcher (2nd ed.). Sage.

Creswell, J.W., \& Poth, C.N. (2018). Qualitative inquiry \& research design: Choosing among five approaches (4th ed.). Sage.

Crofts, K. (2014). What drives the construction of reports and other accountability mechanisms in Australian faith-based social service not-for-profit organizations? Third Sector Review, 20(2), 5778.

Davis, G.F., \& Cobb, J.A. (2009). Resource dependence theory: Past and future. In S.B. Bacharach (Ed.), Research in the Sociology of Organizations (pp. 21-42). Elsevier, London.

Del Mar Gálvez-Rodríguez., M., Caba-Pérez, C., \& López-Godoy, M. (2016). Drivers of twitter as a strategic communication tool for non-profit organizations. Internet Research, 26(5), 1052-1071.

Der Wal, Z., Graycar, A., \& Kelly, K. (2016). See no evil, hear no evil? Assessing corruption risk perceptions and strategies of Victorian public bodies. Australian Journal of Public Administration, 75(1), 3-17.

Dong, W., Liao, S., \& Zhang, Z. (2018). Leveraging financial social media data for corporate fraud detection. Journal of Management Information Systems, 35(2), 461-487.

Donnelly, K.S. (2010). Good governance: Has the IRS usurped the business judgment of tax-exempt organizations in the name of transparency and accountability? UMKC Law Review, 79(1), 163193.

ECFA. (2020). ECFA's Integrity Standards for Nonprofits. Retrieved July 28, 2020, from https://www.ecfa.org/Standards.aspx

Enofe, A., \& Amaria, P. (2011). The role of the church denomination in financial accountability among religious organizations. International Journal of Business, Accounting, \& Finance, 5(2), 87-104.

Erasmus, B., \& Morey, P.J. (2016). Faith-based volunteer motivation: Exploring the applicability of the volunteer functions inventory to the motivations and satisfaction levels of volunteers in an Australian faith-based organization. Voluntas, 27(3), 1343-1360.

Eraut, M. (2004). Informal learning in the workplace. Studies in Continuing Education, 26(2), 247-273.

Feng, N.C., Daniel, G.N., \& Slatten, L.A.D. (2019). Stakeholder groups and accountability accreditation of non-profit organizations. Journal of Public Budgeting, Accounting \& Financial Management, $31(2), 218-236$.

Financial Accounting Standards Board (FASB). (2016). Accounting standards update (No. 2016 14). Retrieved from https://www.fasb.org/jsp/FASB/FASBContent_C/CompletedProjectPage \&cid $=1176168381520$

Fitzgerald, B.C., Omer, T.C., \& Thompson, A.M. (2018a). Audit partner tenure and internal control reporting quality: U.S. evidence from the not-for-profit sector. Contemporary Accounting Research, 35(1), 334-364.

Fitzsimons, A.P., McCarthy, I.N., \& Silliman, B.R. (2018b). FASB issues new guidance to improve financial reporting for not-for-profit organizations. Review of Business, 38(1), 36-46.

France, A., \& Tang, W. (2018). Stakeholder accountability of a non-profit organisation subsidiary. New Zealand Journal of Applied Business Research, 16(1), 19-33.

Gartland, D.J. (2016). Risks of not-for-profit and government audits. Journal of Accountancy, 221(4), 1618.

Gates, S., Prachyl, C.L., \& Sullivan, C. (2016). Using report to the nations on occupational fraud and abuse to stimulate discussion of fraud in accounting and business classes. Journal of Business and Behavioral Sciences, 28(1), 106-115.

Geer, B.W., Maher, J.K., \& Cole, M.T. (2008). Managing nonprofit organizations: The importance of transformational leadership and commitment to operating standards for nonprofit accountability. Public Performance \& Management Review, 32(1), 51-75.

Gelling, L. (2015). Stages in the research process. Nursing Standard, 29(27), 44. 
Gibson, M. (2018). An analysis of fraud prevention and detection in not-for-profit organizations in the State of South Carolina (Doctoral dissertation, Liberty University).

Giving USA. (2018). The annual report on philanthropy for the year 2016: Indiana University Lilly family school of philanthropy. Giving USA Foundation.

Hager, M.A., \& Hedberg, E.C. (2016). Institutional trust, sector confidence, and charitable giving. Journal of Nonprofit \& Public Sector Marketing, 28(2), 164-184.

Harris, E., Petrovits, C., \& Yetman, M.H.J.J. (2017). Why bad things happen to good organizations. The Link Between Governance and Asset Diversions in Public Charities, 146(1), 149-166.

Hauser, C. (2019). Fighting against corruption: Does anti-corruption training make any difference? Journal of Business Ethics, 159(1), 281-299.

Haynes, J. (2009). Conflict, conflict resolution and peacebuilding: The role of religion in Mozambique, Nigeria and Cambodia. Commonwealth \& Comparative Politics, 47, 52-75.

Hou, J., Zhang, C., \& King, R.A. (2017). Understanding the dynamics of the individual donor's trust damage in the philanthropic sector. Voluntas, 28(2), 648-671.

Jackson, S.L. (2015). The vexing problem of defining financial exploitation. Journal of Financial Crime, 22(1), 63-78.

Jensen, M.C. (1993). The modern industrial revolution, exit, and the failure of internal control systems. Journal of Finance, 48(3), 831-880.

Kummer, T., Singh, K., \& Best, P. (2015). The effectiveness of fraud detection instruments in not-forprofit organizations. Managerial Auditing Journal, 30(4), 435-455.

Majid, R.A., Basri, S.A., Mohamed, N., \& Ahmad, K. (2016). The commitment of local authorities in building fortress against misappropriation of assets. Malaysian Accounting Review, 15(2), 231241.

Mazar, N., Amir, O., \& Ariely, D. (2008). The dishonesty of honest people: A theory of self-concept maintenance. Journal of Marketing Research, 45(6), 633-644.

McDonnell, D., \& Rutherford, A.C. (2018). The determinants of charity misconduct. Nonprofit \& Voluntary Sector Quarterly, 47(1), 107-125.

McKay, T., \& Maboya, M. (2019). The financial sustainability challenges facing the South African nonprofit sector. TD: The Journal for Transdisciplinary Research in Southern Africa, 15(1), 1-10.

McMahon, R., Pence, D., Bressler, L., \& Bressler, M.S. (2016). New tactics in fighting financial crimes: Moving beyond the fraud triangle. Journal of Legal, Ethical and Regulatory Issues, 19(1), 16.

Milde, K., \& Yawson, R. M. (2017). Strategies for social media use in nonprofits. Journal of Management Policy and Practice, 18(1), 19-27.

Morales, S.R., \& Cabello, M.C. (2015). Integrating character in management: Virtues, character strengths, and competencies. Business Ethics: A European Review, 24, S156-S174.

Murphy, M.L. (2015). Preventing and detecting fraud at not-for-profits. Journal of Accountancy, 220(6), $77-83$

Nakhid, C. (2015). Community advisory groups in research with "selective" communities: Pacific island youth in South Auckland, New Zealand. International Journal of Interdisciplinary Social \& Community Studies, 10(3), 37-49.

Nasir, N.A.B.M., Ali, M.J., \& Ahmed, K. (2019). Corporate governance, board ethnicity and financial statement fraud: Evidence from Malaysia. Accounting Research Journal, 32(3), 514-531.

NJ. (2019). Department of Labor. Retrieved from https://www.nj.gov/labor/lpa/dmograph/est/est_index.html

O'Gara, J.D. (2014). Corporate fraud: Case studies in detection and prevention. John Wiley \& Sons, Inc.

Palvo, W. (2013). Walter. Forbes. Retrieved from http://www.forbes.com/sites/walterpavlo fraudthrivingin-U-S-churches-but-you-wouldnt-know-it/

Patelli, L., \& Pedrini, M. (2015). Is tone at the top associated with financial reporting aggressiveness? Journal of Business Ethics, 126(1), 3-19. 
Pedersen, B., Delmar, C., Falkmer, U., \& Grønkjaer, M. (2016). Bridging the gap between interviewer and interviewee: Developing an interview guide for individual interviews by means of a focus group. Scandinavian Journal of Caring Sciences, 30(3), 631-638.

Percy, W.H., \& Kostere, K. (2015). Generic qualitative research in psychology. The Qualitative Report, 20(2), 76-85.

Pezalla, A.E., Pettigrew, J., \& Miller-Day, M. (2012). Researching the researcher-as-instrument: An exercise in interviewer self-reflexivity. Qualitative Research, 12(2), 165-185.

Pickerd, J.S., Summers, S.L., \& Wood, D.A. (2015). An examination of how entry-level staff auditors respond to tone at the top vis-à-vis tone at the bottom. Behavioral Research in Accounting, 27(1), 79-98.

Rae, K., Sands, J., \& Subramaniam, N. (2017). Associations among the five components within COSO internal control-integrated framework as the underpinning of quality corporate governance. Australasian Accounting Business \& Finance Journal, 11(1), 28-54.

Ramanath, R. (2016). Unpacking donor retention: Individual monetary giving to U.S.-based Christian faith-related, international nongovernmental organizations. Religions, 7(11), 133.

Sabau, A.S. (2012). Survey of clustering based financial fraud detection research. Informatica Economica, 16(1), 110-122.

Said, J., Alam, M.M., Karim, Z.A., \& Johari, R.J. (2018). Integrating religiosity into fraud triangle theory: Findings on Malaysian police officers. Journal of Criminological Research, Policy and Practice, $4(2), 111-123$.

Sankaran, S., Dick, B., Shaw, K., Cartwright, C., Davies, A., Kelly, J., \& Vindin, B. (2014). Application of scenario-based approaches in leadership research: An action research intervention as three sets of interlinked practices. Systemic Practice \& Action Research, 27(6), 551-573.

Sanz, P., \& Fontrodona, J. (2019). Moderation as a moral competence: Integrating perspectives for a better understanding of temperance in the workplace. Journal of Business Ethics, 155(4), 981994.

Schaubroeck, J.M., Hannah, S.T., Avolio, B.J., Kozlowski, S.W., Lord, R.G., Treviño, L.K., \& Peng, A.C. (2012). Embedding ethical leadership within and across organization levels. Academy of Management Journal, 55(5), 1053-1078.

Schürmann, E., \& Beausaert, S. (2016). What are drivers for informal learning? European Journal of Training and Development, 40(3), 130-153.

Segal, S.Y. (2016). Accounting frauds - Review of advanced technologies to detect and prevent frauds. Economics and Business Review, 2(4), 45-64.

Self, S., Fudge, T., Sullivan, G., \& Harrington, T. (2016). Business acquisition: A case study with various accounting frauds. International Journal of Business, Accounting, \& Finance, 10(2), 15-24.

Shafer, W.E., Simmons, R.S., \& Yip, R.W.Y. (2016). Social responsibility, professional commitment and tax fraud. Accounting, Auditing \& Accountability Journal, 29(1), 111-134.

Shaharuddin, S., \& Sulaiman, M. (2015). Financial disclosure and budgetary practices of religious organization: A study of Qaryah Mosques in Kuala Terengganu. Gadjah Mada International Journal of Business, 17(1), 83-101.

Sider, R.J., \& Unruh, H.R. (2004). Typology of religious characteristics of social service and educational organizations and programs. Nonprofit and Voluntary Sector Quarterly, 33(1), 109-134.

Simon, M.K., \& Goes, J. (2013). Dissertation and scholarly research: Recipes for success (2013 Ed.). Dissertation Success, LLC.

Smith, K., Thew, G., \& Graham, B. (2018). Conducting ethical internet-based research with vulnerable populations: A qualitative study of bereaved participants' experiences of online questionnaires. European Journal of Psychotraumatology, 9(sup1), 1506231. https://doi.org/10.1080/20008198.2018.1506231

Sorunke, O.A. (2016). Personal ethics and fraudster motivation: The missing link in fraud triangle and fraud diamond theories. International Journal of Academic Research in Business and Social Sciences, 6(2), 159-165. 
Stake, R.E. (2010). Qualitative research: Studying how things work. Guilford Press.

Steimel, S. (2018). Skills-based volunteering as both work and not work: A tension-centered examination of constructions of "volunteer". VOLUNTAS: International Journal of Voluntary and Nonprofit Organizations, 29(1), 133-143.

Stephens, J., \& Flaherty, M.P. (2013). Inside the hidden world of thefts, scams and phantom purchases at the nation's nonprofits. The Washington Post. Retrieved fromhttp://www.washingtonpost.com

Sulaiman, M., Siraf, S.A., \& Mohamed Ibrahim, S.H. (2008). Internal control systems in West Malaysia's state mosques. American Journal of Islamic Social Sciences, 25(1), 63-81.

Thacker, C., Sullivan, G., \& Self, S.W. (2019). How servant leadership principles affect employee turnover at a solid waste management firm. Journal of Leadership, Accountability and Ethics $16(2), 15$.

Thornhill, R., \& Domino, M.A. (2016). Passing the plate: A survey of internal controls in local churches. Journal of Theoretical Accounting Research, 12(1), 26-53.

Tinkelman, D.P., \& Song, Y. (2012). If asset misappropriation is so common, why do so few public companies disclose it? Journal of Forensic Studies in Accounting \& Business, 4(1), 65-82.

Tiwari, R.K., \& Debnath, J. (2017). Forensic accounting: A blend of knowledge. Journal of Financial Regulation and Compliance, 25(1), 73-85.

Toner, P., \& Woolley, R. (2016). Perspectives and debates on vocational education and training, skills and the prospects for innovation. Revista Espanola De Sociologia, 25(3), 319-342.

Vasileiou, K., Barnett, J., Thorpe, S., \& Young, T. (2018). Characterising and justifying sample size sufficiency in interview-based studies: Systematic analysis of qualitative health research over a 15-year period. BMC Medical Research Methodology, 18, 148.

Ventura, M., \& Daniel, S.J. (2010). Opportunities for fraud and embezzlement in religious organizations: An exploratory study. Journal of Forensic and Investigative Accounting, 2(1), 1-35.

Warren, D.E., Peytcheva, M., \& Gaspar, J.P. (2015). When ethical tones at the top conflict: Adapting priority rules to reconcile conflicting Tones. Business Ethics Quarterly, 25(4), 559-582.

Wells, J.T. (2013). Corporate fraud handbook: Prevention and detection. Retrieved from https://ebookcentral-proquest-com.ezproxy.liberty.edu

Wolfe, D.T., \& Hermanson, D.R. (2004). The fraud diamond: Considering the four elements of fraud. The CPA Journal, 74(12), 38-42.

Xu, B., Bhuiyan, M.B.U., \& Rahman, A. (2016). Underlying profit in New Zealand. Pacific Accounting Review, 28(2), 111-134.

Yasmin, S., Haniffa, R., \& Hudaib, M. (2014). Communicated accountability by faith-based charity organizations. Journal of Business Ethics, 122(1), 103-123.

Yin, R.K. (2014). Case study research: Design and methods (5th ed.). Sage.

Zuberi, O., \& Mzenzi, S.I. (2019). Analysis of employee and management fraud in Tanzania. Journal of Financial Crime, 26(2), 412-431. 


\section{APPENDIX A: INTERVIEW QUESTIONS}

1. What competencies, accounting education and accounting experience do you possess as your organization's financial administrator that enable you to understand financial internal controls?

What is your full time professional or job inside and/or outside of your organization?

Demographic data collected: Gender / Age / General Education Level / Specialized Accounting or Financial certification

2. What is the nature of services that your religious organization provides to the public?

3. What is the size of your religious entity's budget?

4. What is your leadership role in the entity?

5. Are you employed as a paid employee or as a paid or unpaid volunteer?

6. In your role, do you provide financial management support in the organization?

7. How long have you served in your role in making financial decisions for the religious enterprise?

8. What financial training have you taken to support your leadership role in your religious organization?

9. Who do you believe has the fiduciary responsibility for protecting the organization's resources?

10. How has your professional or non-professional experience equipped you to detect potential fraud, mismanagement, misappropriation, or abuse in your religious entity?

11. What types of decisions have you made concerning the financial management of NPO resources?

12. What measures, if any, does your organization have to manage fraud or misappropriation of funds?

13. What type of fund-raising efforts your organization is involved with?

14. Does the fund-raising efforts include high cash transactions?

15. Do you feel that your religious enterprise is fully protected against fraud?

16. What control activities are in place by management to dissuade fraud theft and fraudulent activities?

17. What additional training is required for you to strengthen your financial competencies to safeguard the organization's resources adequately?

18. What is your opinion of implementing the following practices to enhance financial stewardship of the organization's leaders: 1) Creating segregation of duties for the accounting operations if not already in place; 2) Having a CPA or a qualified financial professional annually audit the organization financial statements; and 3) Creating checks and balances of bookkeeping procedures?

19. Describe your understanding of sound financial accounting principles such as generally accepted accounting principles or the accounting regulations issued by the Financial Accounting Standard Board as it relates to the religious organizations?

20. What internal control does your organization have in place to deal with fraud committed by leadership versus fraud committed by non-leadership?

21. How do you feel about the financial transparency of the organization?

22. Describe if your organization has ever done a risk assessment to determine its vulnerability to fraud?

23. Are you and your Board of directors satisfied with the organization's ability to detect and deter fraud?

24. Describe how you, as an enterprise leader would respond to acts of fraud, waste, mismanagement, abuse, or misappropriation in the church?

25. When you hear about fraudulent actions against the religious organization, how do you feel, and do these stories cause you to look at your current internal control?

26. What else do you want to share regarding your ability to promote sound financial stewardship in securing the entity's resources?

27. What ongoing training, if any, does your organization have for leaders and financial stewards?

28. Are there any questions or comments you would like to add? 